\title{
PIPE STEELS WITH ENHANCED CORROSION RESISTANCE
}

Translated from Metallovedenie i Termicheskaya Obrabotka Metallov, No. 10, p. 3, October, 2012.

A steady tendency in the world engineering progress is expansion of pipeline transportation, where the oil and gas producing industries with developed systems of transportation of their products to their consumers dominate. The main components of the transporting systems are steel pipes the quality of which is progressively advanced by metallurgists. Some advancements of the last $15-20$ years have almost doubled the consumer properties of oil and gas pipes (strength, ductility, corrosion resistance, endurance, etc.). The corrosion aggressiveness of the extracted products has also increased substantially due to the late stages of exploitation of the active deposits (elevation of the watering and of the level of mineralization) and higher corrosion activity of the environment of new oil fields.

Today the reliability and endurance of the extracting facilities and oil transporting systems is not high. Specifically, according to the data of extracting organizations $35-$ 40 thousand incidents accompanied by oil release (into water basins inclusive) occur at the domestic oil lines of the Russian Federation, which are 350 thousand kilometers long. The same situation is typical for the oil producing equipment. Safe service life of tubing hangers in many oil wells is
$3-6$ months. The main cause of degradation and failure of tubing is internal corrosion that depends of the composition of the extracted environment and manifests itself though the following kinds of corrosion-mechanical fracture or their combination: hydrogen cracking, stress sulfide corrosion cracking, carbon dioxide and bacterial pitting corrosion.

There is a need for a new direction in the development of steels for oil and gas pipes for providing high mechanical properties combined with resistance to the mentioned kinds of corrosion. The task can be solved on the basis of reliable data on adequacy of the mechanisms and kinetics of the evolution of corrosion damage in laboratory and field tests, on the relation between the composition of a steel and the formed corrosion products, on the effect of the content, shape and constitution of nonmetallic inclusions on the corrosion resistance of steels.

The results of research devoted to these topics and data on the developed steels 13KhFChA, 08KhMFChA and $15 \mathrm{Kh} 5 \mathrm{MFBCh}$ and on regimes of their heat treatment providing an optimum combination of mechanical and corrosion properties are presented in the papers issued below. 